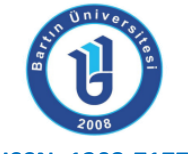

ISSN: 1308-7177

\title{
İlköğretim Matematik Öğretmeni Adaylarının Mesleği Tercih için Güdülenmeleri: Ölçek Geçerlik ve Güvenirlik Çalışması
}

Serhat AYDIN, Karamanoğlu Mehmetbey Üniversitesi, Eğitim Fakültesi, aydins@kmu.edu.tr Derya ÇELIK, Karadeniz Teknik Üniversitesi, Fatih Eğitim Fakültesi, deryacelik2@gmail.com

Özet: Bu çalışmanın amacı TEDS-M öğretmenlik mesleği için güdülenme ölçeğinin geçerlik ve güvenirlik çalışması sonuçlarını ortaya koymaktır. Araştırmanın örneklemini, yedi farklı üniversitede ilköğretim matematik öğretmenliği lisans eğitimi gören 583 son sınıf öğretmen adayı oluşturmaktadır. Ölçeğin yapı geçerliğini belirlemek amacıyla açımlayıcı ve doğrulayıcı faktör analizi yapılmıştır. Faktör analizleri sonucunda ölçeğin iç güdülenme ve dış güdülenme şeklinde iki faktörde toplandığı gözlenmiştir. Ölçeğin tamamının açıkladığı varyans \% 50, Cronbach alfa güvenirliği 0.75 ve Mc Donald omega güvenirliği 0.85 olarak bulunmuştur. Ölçeğin her iki faktörü için de güvenirlik katsayıları 0.74 üzerinde ve madde-toplam korelasyonları 0.54 üzerinde bulunmuştur. Sonuç olarak, öğretmenlik mesleği için güdülenmenin içsel ve dışsal olmak üzere iki grup nedenden kaynaklandığı, uyarlaması yapılan ölçeğin geçerli ve güvenilir bir yapıya sahip olduğu ve yapılacak olan bilimsel çalışmalarda kullanılabileceği belirlenmiştir. güvenirlik

Anahtar sözcükler: Öğretmen mesleği için güdülenme, iç güdülenme, dış güdülenme, geçerlik,

\section{Preservice Elementary Mathematics Teachers' Motivations to Choose the Profession: Scale Adaptation and Validation Study}

\begin{abstract}
The aim of this study is to present the results of the validity and reliability study of the TEDS-M scale of motivation to choose teaching profession. The study sample consisted of 583 preservice elementary mathematics teachers studying in seven different universities in Turkey. Exploratory and confirmatory factor analyses were used to test the structural validity of the scale. Factor analyses revealed a two-factor structure such as intrinsic and extrinsic motivation. The total variance explained by the whole scale was found to be $\% 50$, Cronbach alfa reliability coefficient was found as $0.75 \mathrm{Mc}$ Donald Omega was found as 0.85 . For both factors of the scale the reliability coefficients were found above 0.74 and item-total correlations above 0.54 . In conclusion, it was shown that motivation to become a teacher consisted of two factors such as intrinsic and extrinsic reasons, the Turkish form of the scale has a valid and reliable structure and could be used in future studies.
\end{abstract}

Key Words: Motivation to be a teacher, intrinsic motivation, extrinsic motivation, validity, reliability

\footnotetext{
* Bu çalışma 113K805 no'lu proje kapsamında TÜBITAK tarafından desteklenmiştir.
} 


\section{GíRiş}

Güdülenme, davranışların bireyin ihtiyaçlarına bağlı olarak bir hedefe yöneltildiği bir süreç olarak tanımlanmaktadır (Maslow, 1970). Kavram her ne kadar içsel bir mekanizmayı tarif etse de dış nedenlerden de etkilenmektedir (Keller, 1999). Dolayısıyla güdülenme, hem iç hem de dış nedenler tarafından belirlenen ve kişiyi bir davranışı yapmaya iten güç olarak tanımlanabilir. Bu güç insanların neyi neden yaptıklarını belirleyen en önemli değişkenlerden biri olarak görülmektedir (Efklides, Kuhl, \& Sorrentino, 2001). Bir meslek için güdülenme çeşitli meslekler arasından kişinin en iyi yapabileceğini düşündüğü ve kendisine en üst düzeyde doyum sağlayacağına inandığı mesleğe yönelmesi şeklinde tanımlanmıştır (Atav ve Altınoğlu, 2013). Öğretmenlik mesleği için güdülenme; bir bireyin öğretmenlik mesleğini seçmek, mesleğinde başarılı olmak ve mesleğini en iyi şekilde icra etmek için ne kadar kararlı ve azimli olduğunu açıklamaktadır. Bu güdülenme süreci iç doyum (Lloyd, Bond ve Flaxman, 2017) kadar dış doyum (Friedman, 2016) arayışından da kaynaklanabilir.

Farklı seviyelerde ve branşlarda öğretmenler ve öğretmen adaylarının öğretmenlik mesleği için güdülenme nedenleri önemli bir araştırma konusu olarak görülmüş ve çeşitli araştırmalarda incelenmiştir (Behymer ve Cockriel, 1998; Çermik, Doğan ve Şahin, 2010; Friedman, 2016; Kniveton, 2004; Şeker, Deniz ve Görgen, 2015). Çermik ve diğ. (2010), bu konuya olan ilgiyi; öğretmenlik mesleğinin ülkenin sosyal, ekonomik ve kültürel kalkınmasındaki önemli rolü ile açıklamaktadır. Öğretmenlik mesleği için güdülenme nedenlerini belirlemekle önemli sorulara yanıtlar bulunabilir. Örneğin daha yetenekli insanların hangi güdülenme nedenleriyle bu mesleğe geldikleri ortaya konulabilir. Bu bilgi ülke kalkınması için üstün özelliklere sahip gençlerin öğretmenlik mesleğine nasıl kazandırılabileceğini belirlemekte kullanılabilir (Tatto ve diğ., 2008). Kişinin erken yaşlarda yapmak zorunda olduğu ve sonraki yaşamını etkileme gücüne sahip olan meslek seçiminin (Atav ve Altınoğlu, 2013) sosyal kimlik, yaşama sevinci ve doyum sağlama üzerine önemli etkileri vardır (Alberts, Mbalo ve Ackermann 2003). Öğretmenlik mesleği için güdülenme nedenleri ise kişinin kendisi kadar toplumu ve gelecek nesilleri de ilgilendirecek bir önem taşımaktadır (Baumert ve Kunter 2006; Kunter ve Pohlmann 2009; Richardson ve Watt 2006).

Öğretmenlik mesleği için güdülenme nedenlerini araştıran çalışmalar değişik amaçlarla yapılmakla beraber temel olarak güdülenme nedenlerini benzer gruplar altında sınıflandırmışlardır. On yedi ülkede son sınıfta okuyan sınıf ve matematik öğretmeni adaylarının öğretmenlik mesleği için güdülenme nedenlerini araştıran uluslararası karşılaştırmalı TEDS-M çalışmasında, açıklanan nedenlerin; "içsel nedenler" ve "dışsal nedenler" olmak üzere iki örtük özellik(faktör) etrafında toplandığı belirlenmiştir (Tatto ve diğ., 2008). Friedman (2016), 160 öğretmen adayının öğretmenliği tercih nedenlerini araştırdığı çalışmada, nedenleri 1. Gerçek dışsal, 2. Ebeveynlere bağlı dışsal, 3. Gerçek içsel ve 4. Yararlı içsel olmak üzere dört örtük özellik(faktör) etrafında incelemiştir. Kaya ve Yıldırım (2015), fen fakültesi, biyoloji bölümünde okuyan 160 öğrencinin öğretmenliği tercih etme olasılıkları ve nedenlerini incelemişlerdir. Bu çalışmada lisans öğrencilerinin öğretmenliği tercih etme nedenleri, "Öğretmen olma durumunda mutlu olacağıma inandığım için" gibi içsel veya "Biyolog olarak iş bulamayacağımı düşündüğüm için" gibi dışsal olarak iki kategori altında sınıflandırılmıştır. Çermik ve diğ. (2010), 157 sınıf öğretmeni adayı ile yaptıkları çalışmada açık uçlu sorular kullanarak öğretmen adaylarının öğretmenliği tercih etme nedenleri ve güdülenmelerini belirlemeye çalışmışlardır. Çalışmada yapılan söylem ve içerik analizleri ile öğretmen adaylarının öğretmenlik mesleği için güdülenme nedenleri 1. Dışsal, 2. İçsel, 3. Çıkarcı ve 4. Özgeci olmak üzere dört başlık altında toplanmıştır. Diğer bazı çalışmalarda da öğretmen adaylarının öğretmenliği tercih etme nedenleri dış ve iç nedenler şeklinde iki örtük özellik(faktör) etrafında belirlenerek dışsal 
nedenlerin içsel nedenlere baskın olduğu bildirilmiştir (Bastick, 2000; Boz ve Boz, 2008; Papanastasiou ve Papanastasiou, 1997; 1998; Saban, 2003).

Tüm bu çalışmalar incelendiğinde Türkiye'de öğretmenlik mesleği için güdülenme nedenlerini araştıran çalışmaların sayıca azlığı ve bu çalışmaların çoğunda nitel mülakatlar ve söylem analizlerine odaklanıldığı görülmektedir. Konuyla ilgili geçerli ve güvenilir Türkçe ölçeklerin azlığı dikkat çekmektedir. Bu durum dikkate alındığında, uluslararası TEDS-M çalışmasında geliştirilen ve 17 ülkede 8000'den fazla öğretmen adayı için kullanılan "Öğretmenlik Mesleği için Güdülenme" ölçeğinin Türkçe'ye uyarlanması ve geçerlik ve güvenirliğinin kanıtlanmasının yararlı olacağı görülmektedir. Tüm bu gerekçelerle çalışmanın araştırma problemleri şu şekilde oluşturulmuştur:

1. Türkçe'ye uyarlanmış TEDS-M “Öğretmenlik Mesleği için Güdülenme” ölçeğinin geçerliği hangi düzeydedir?

2. Türkçe'ye uyarlanmış TEDS-M “Öğretmenlik Mesleği için Güdülenme” ölçeğinin güvenirliği hangi düzeydedir?

\section{YÖNTEM}

Bu çalışma bir ölçek geçerlik ve güvenirlik çalışmasıdır. Çalışmada İngilizce'den Türkçe'ye uyarlanmış olan bir ölçeğin temsil yeteneği yüksek bir örneklemde uygulanması ve daha sonra geçerlik ve güvenirlik analizlerinin yapılması anlatılmaktadır. Geçerlik kanıtları olarak açımlayıcı ve doğrulayıcı faktör analizleri sonuçları ortaya konulmuştur. Güvenirlik kanıtları olarak ölçeğin her bir faktörü için madde-toplam korelasyonları ile birlikte Cronbach alfa, Mc Donald Omega ve En Büyük Alt Sınır (Greatest Lower Bound) değerlerine bakılmıştır.

\section{1. Çalışma Grubu}

Çalışmanın evreni, ülkemizdeki ilköğretim matematik öğretmenliği programına 2014 yılı itibarıyla öğrenci kabul eden 48 üniversitede okuyan tüm son sınıf ilköğretim matematik öğretmeni adaylarıdır (IMÖA). Çalışmanın örneklemi; evren içerisinden her coğrafi bölgeden, o bölgeyi temsil etme niteliği taşıdığı düşünülen bir üniversite rastgele seçilerek oluşturulan 7 üniversitede okuyan ve çalışmaya gönüllü katılmak isteyen tüm son sınıf ilköğretim matematik öğretmeni adayıdır. Bu çalışma kapsamında ele alınan 7 üniversite ve bu üniversitelerden çalışmaya katılan toplam 583 iMÖA'nın genel özellikleri Tablo 1'de gösterilmektedir. Çalışmada incelenen üniversiteler etik nedenlerle sırasıyla Akdeniz bölgesinden Ü-akd üniversitesi, Doğu Anadolu bölgesinden Ü-doğ üniversitesi, Ege bölgesinden Ü-ege üniversitesi, Güneydoğu Anadolu bölgesinden Ü-gün üniversitesi, İç Anadolu bölgesinden Ü-iça üniversitesi, Karadeniz Bölgesinden Ü-kar üniversitesi ve Marmara bölgesinden Ü-mar üniversitesi şeklinde kodlanmıştır.

Tablo 1

Çalışmanın Örneklemi

\begin{tabular}{llccc}
\hline Üniversite & Coğrafi Bölge & N & Yaş Ortalaması & $\begin{array}{c}\text { Cinsiyet } \\
\text { Kadın / Erkek }\end{array}$ \\
\hline Ü-akd & Akdeniz & 54 & 22.60 & $36 / 18(2.00)$ \\
Ü-doğ & Doğu Anadolu & 41 & 22.20 & $15 / 26(0.57)$ \\
Ü-ege & Ege & 97 & 22.48 & $67 / 29(2.31)$ \\
Ü-gün & Güneydoğu Anadolu & 50 & 22.35 & $29 / 21(1.38)$ \\
Ü-iça & İç Anadolu & 71 & 23.39 & $59 / 12(4.91)$ \\
Ü-kar & Karadeniz & 175 & 21.64 & $127 / 47(2.70)$ \\
Ü-mar & Marmara & 95 & 22.22 & $66 / 29(2.27)$ \\
& TOPLAM & 583 & & \\
\hline
\end{tabular}


Tablo 1'e bakıldığı zaman örneklemde üniversitelere ait yaş ortalaması $21.64-23.39$ aralığıyla, bir üniversite dışında doğudan batıya doğru düşüş göstermektedir. Çalışmanın örnekleminde yer alan üniversitelerde okuyan iMÖA'nın kadın erkek oranı ise 0.57 ve 4.91 arasında geniş bir aralık göstermektedir. Çalışmaya katılan 583 iMÖA'dan 399'u (\%68.4) kadın, 184'ü (\%31.6) erkektir. Bunlardan 259'u (\%44.4) birinci öğretim, 219'u (\%37.6) ikinci öğretimde öğrenim görmektedir. Diğer yandan 105 (\%18) iMÖA'nın öğrenim gördüğü program türü bilgisi eksiktir.

\subsection{Veri Toplama Aracı}

Bu araştırmada TEDS-M Öğretmenlik Mesleği için Güdülenme Ölçeği Türkçe formunun geçerlik ve güvenirlik analizleri incelenmektedir. Orijinal ölçek on yedi ülkede son sınıfta okuyan sınıf ve matematik öğretmeni adaylarının öğretmenlik mesleği için güdülenme nedenlerini uluslararası karşılaştırmalı olarak araştırmak için geliştirilmiştir (Tatto vd., 2008). TEDS-M çalışmasında, geliştirilen dokuz soruluk ölçeğin "içsel nedenler" (6 madde) ve "dışsal nedenler" ( 3 madde) olmak üzere iki örtük özellik(faktör) etrafında toplandığı belirlenmiştir (Tatto vd., 2008). Ölçeğe verilen cevaplar; 1) Bu bir neden değil, 2) Bu küçük bir neden, 3) Bu önemli bir neden ve 4) Bu en önemli nedenlerden biri şeklinde dörtlü Likert tipindedir. Ölçeğin her iki faktörü için ortalama veya toplam puanlar ayrı ayrı hesaplanmaktadır. Orijinal ölçeğin geçerli ve güvenilir olduğu bildirilmiş fakat geçerlik ve güvenirlik katsayıları henüz yayınlanmamıştır.

\section{3. İşlem}

Çalışmada öncelikle tercüme ve düzeltme işlemleri yapılmıştır. Daha sonra elde edilen Türkçe form uygun bir örnekleme ( 7 farklı coğrafi bölgeden toplam 7 üniversiteden 583 ilköğretim matematik öğretmeni adayı) uygulanarak analizler için bir veri seti elde edilmiştir. Elde edilen veri setinin öncelikle faktör analizlerine uygunluğu incelenmiştir. Bu amaçla normallik testleri yapılmış, kayıp ve uç değerler belirlenerek bunların nasıl ele alınacağına karar verilmiş, çoklu doğrusallık ve tekillik testleri yapılmış, örneklem büyüklüğünün faktör analizlerine uygunluğu ve çok boyutlu normallik varsayımlarının karşılanıp karşılanmadığı (Bartlett küresellik testiyle) araştırımış, son olarak ta madde-madde ve anti-image korelasyonlar matrislerinde bir sorun olup olmadığına bakılmıştır. Tüm bu değerlendirmeler sonucunda eldeki veri setinin faktör analizlerine uygunluğuna karar verilmiştir. Bu aşamada öncelikle geçerlik kanıtı olarak açımlayııı faktör analizleri (AFA) yapılmıştır. Geçerlik kanıtları olarak daha sonra doğrulayıcı faktör analizleri (DFA) yapılmıştır. AFA'da ölçeğin faktör yapısını belirlemek için açıklanan toplam varyans miktarı, faktör yük değerleri ve dört testin (Kaiser, Cartell, Velicer ve Horn) sonuçlarına bakılmıştır. DFA'da ise eldeki veri setinin kurulan modele uyum parametreleri yorumlanmıştır. Güvenirlik analizleri olarak önce madde-toplam korelasyonlarına daha sonra alfa, omega ve GLB iç tutarlılık güvenirlik katsayıları ve güven aralıklarına bakılmıştır. Son olarak tüm analizler birlikte yorumlanarak ölçeğin faktör yapısı ve bazı zayıf maddelerin nasıl ele alınacağına karar verilmiştir.

\section{BULGULAR}

Bu bölümde çalışmanın bulguları açıklanarak yorumlanmıştır.

\subsection{Tercüme ve Düzeltme Süreci}

Ölçeğin İngilizce'den Türkçe'ye tercümesi için çoklu tercüme ve çoklu düzeltme yöntemi kullanılmıştır. Ölçeğin tercümesi bir matematik eğitimi, bir eğitim bilimleri ve bir İngiliz dili ve edebiyatı uzmanı üç öğretim üyesi tarafından yapılmıştır. Sonra araştırmacılar tarafından bu tercümeler bir matris şeklinde bir araya toplanmıştır. Bu matriste tercüme edilecek maddelerin sayısı kadar satır bulunmaktadır. Sütunlarda ise kaynak dilde madde, bu 
maddelerin farklı tercümeleri ve araştırmacıların seçtiği en iyi tercüme şeklinde beş sütun bulunmaktadır. Daha sonra tercümanlar bu matrisi inceleyerek en iyi tercüme alternatifleri hakkında yorumlarda ve düzeltmelerde bulunmuşlardır. Düzeltme sürecinden sonra en son araştırmacılar her madde için bir ideal tercüme seçmişlerdir. Bu yöntem tekil tercüme ve düzeltme ile tercüme-geri tercüme yöntemlerinden üstün bir yöntemdir ve TIMMS, PISA ve TEDS-M araştırmalarında kullanılmıştır (Aydın, 2014).

\subsection{Tercüme Ölçeğin Uygulanması}

Türkçe ölçek bu çalışmada temsil yeteneği yüksek olan bir örneklemde uygulanmıştır. $\mathrm{Bu}$ örneklemden elde edilen veri seti, daha sonra geçerlik ve güvenirlik analizlerinde kullanılmıştır.

\section{Belirlenmesi}

3.3. Uygulamadan Elde Edilen Veri Setinin Faktör Analizine Uygunluğunun

"Öğretmenlik Mesleği için Güdülenme" ölçeğinin psikometrik niteliklerini saptamak amacıyla öncelikle uygulamadan elde edilen veri setinin uygunluğu incelenmiştir. Bu doğrultuda veri seti için normallik, kayıp değerler, uç değerler, çoklu doğrusallık ve tekillik testleri, örneklem büyüklüğü testleri, Bartlett küresellik testi ve korelasyon testleri (maddemadde ve anti-image) yapılmıştır Yapılan analizler sonucunda elde edilen bilgiler aşağıda özetlenmiştir.

\subsubsection{Normallik Testleri:}

“Öğretmenlik Mesleği için Güdülenme" ölçeğinin uygulanmasından elde edilen veri setleri için normallik testleri yapılmıştır. Buna göre, uygulamadan elde edilen veri seti için merkezi eğilim ölçüleri, çarpıklık (kayışlılık) ve basıklık katsayıları hesaplanmıştır. Yapılan analiz sonucunda elde edilen değerler Tablo 2'de verilmiştir.

Tablo 2

Uygulamadan Elde Edilen Veri Seti için Normallik Testleri

\begin{tabular}{|c|c|c|c|c|c|c|c|c|c|c|}
\hline Maddeler & $\mathbf{X}$ & Xort & Mod & $\mathbf{S}$ & S2 & Ky & Bs & Aralık & Min. & Mak. \\
\hline$A$ & 2 & 2.29 & 3 & 0.99 & 0.98 & 0.12 & -1.09 & 3 & 1 & 4 \\
\hline C & 4 & 3.48 & 4 & 0.73 & 0.53 & -1.24 & 1.54 & 5 & 1 & 6 \\
\hline$E$ & 3 & 2.97 & 3 & 0.93 & 0.86 & -0.60 & -0.50 & 3 & 1 & 4 \\
\hline G & 3 & 3.28 & 4 & 0.80 & 0.64 & -0.92 & 0.23 & 3 & 1 & 4 \\
\hline $\mathbf{F}$ & 2 & 1.79 & 1 & 0.83 & 0.70 & 0.79 & -0.12 & 3 & 1 & 4 \\
\hline $\mathbf{I}$ & 3 & 2.68 & 3 & 1.03 & 1.05 & -0.24 & -1.04 & 4 & 1 & 5 \\
\hline \multicolumn{11}{|c|}{ Ölçekteki Faktörlere Ait Normallik Değerleri } \\
\hline \multicolumn{11}{|c|}{9 madde } \\
\hline İç & 18 & 17.81 & 18 & 3.30 & 10.86 & -0.47 & -0.01 & 18 & 6 & 18 \\
\hline \multicolumn{11}{|c|}{8 madde (En Zayıf Olan Madde A'nın Çıkartılmasıyla Elde Edilen) } \\
\hline Dış & 7 & 6.63 & 6 & 2.25 & 5.07 & 0.20 & -0.59 & 10 & 2 & 12 \\
\hline \multicolumn{11}{|c|}{7 madde (En Zayıf Olan Madde A'nın ve Sonra C'nin Çıkartılmasıyla Elde Edilen) } \\
\hline İç & 12 & 12.08 & 12 & 2.51 & 6.30 & -0.43 & -0.24 & 12 & 4 & 16 \\
\hline Dış & 7 & 6.63 & 6 & 2.25 & 5.07 & 0.20 & -0.59 & 10 & 2 & 12 \\
\hline \multicolumn{11}{|c|}{6 madde (En Zayıf Olan Madde A'nın, Sonra C'nin ve Sonra G'nin Çıkartılmasıyla Elde Edilen) } \\
\hline İç & 9 & 8.79 & 9 & 2.06 & 4.26 & -0.42 & -0.30 & 9 & 3 & 12 \\
\hline Dış & 7 & 6.63 & 6 & 2.25 & 5.07 & 0.20 & -0.59 & 10 & 2 & 12 \\
\hline
\end{tabular}


Tablo 2'de görüldüğü üzere, merkezi eğilim ölçüleri birbirine yakın değerler göstermektedir. Çarpıklık ve basıklık değerlerinin 0 ile 1 arasında olması dağılımın normalliğinin kanıtı olarak kullanılabilir (Rosnow ve Rosenthal, 2008). Tüm maddeler ve ölçekteki faktörler için çarpıklık ve basıklık katsayılarının her ikisi de $1^{\prime}$ in altında olduğu ve dağılımın normal olduğu görülmektedir. En zayıf maddeler olan A, C ve G'nin sırasıyla atılması durumunda da normallik varsayımlarının karşılandığı görülmektedir. Bunun yanında maddeler düzeyinde çarpıklık ve basıklık katsayılarının bazı maddeler için normallik sınırlarını biraz aştığı görülmektedir. Burada maddelere verilen cevapların sıralama ölçeği olduğu ve aralığın küçük olduğu dikkate alınmalıdır. Yine de bazı maddelerin analizlerde test edilen modellere uyumsuz çıkması durumunda, o maddeye verilen cevaplardaki çarpıklık ve basıklık değerlerinin normal dağılıma uyumsuz olması neden olarak düşünülebilir.

\subsubsection{Kayıp Değerlerin Belirlenmesi:}

Uygulamadan elde edilen veri seti için madde düzeyinde kayıp değer oranları belirlenmiştir. Veri seti için kayıp değer oranları maddelere göre \% 0 ile \% 0.7 arasında değişirken; toplam 14 maddede kayıp değerler olduğu görülmüştür. Kayıp değer içeren madde sayısı çok az olduğu için bu maddelerin tutulmasına karar verilmiştir.

\subsubsection{Uç Değerlerin (Outliers) Belirlenmesi:}

Uygulamadan elde edilen veri seti için uç değer sayıları belirlenmiştir. Uygulamadan elde edilen ait veri setinde $(n=583) 16$ uç değer tespit edilmiştir. Uç değer olarak SPSS tarafından standart olarak kullanılan (Q1-1.5*IQR, Q3+1.5*IQR) aralığının dışında kalma formülü esas tutulmuştur (Howell, 2007; Tabachnick \& Fidell, 2007). Bu 16 değerden hiçbiri ($3.0<z<3.0)$ aralığı dışında kalmamıştır. Uç değer sayısı az olduğu ve uç değerlerin tamamı tutulmuştur.

\subsection{4. Çoklu Doğrusallık ve Tekillik Testleri:}

Uygulamadan elde edilen veri seti için çoklu doğrusalık ve tekillik analizleri yapılımıştır. Uygulamadan elde edilen veri seti için yapılan analiz sonucunda, maddeler arası korelasyon katsayılarının "iç güdülenme" faktörü için .10 ile .42 ve "dış güdülenme" faktörü için .39 ile .48 arasında değiştiği görülmektedir. Bu doğrultuda, uygulamadan elde edilen veri seti için çoklu doğrusallık ve tekillik sorununun olmadığı ifade edilebilir. Çünkü çoklu doğrusallık için 2 veya daha fazla madde arasında çok güçlü $(r \geq 90)$ korelasyon ve tekillik için $(r=1)$ korelasyon bulunması gerekmektedir (Şekercioğlu, 2009).

\subsection{5. Örneklem Büyüklüğünün Uygunluğu Testleri}

Uyarlaması yapılan ölçeğin Türkçe formunun seçilen örnekleme uygulanması sonucu elde edilen veri setine faktör analizleri yapılmadan önce yapılması gereken bir başka çalışma örneklem büyüklüğünü incelemektir. Bu amaçla burada örneklem büyüklüğünün faktör analizine uygunluğuna bakılmıştır. Bu amaçla üç farklı kriter kullanılabilir. Birinci kriter doğrudan katılımcı sayısına bakarak karar vermektir (Comrey ve Lee, 1992). İkinci seçenekte katılımcı sayısının madde sayısı oranına bakarak karar verilir (Bryman ve Cramer, 2001). Üçüncü seçenekte Kaiser-Meyer-Olkin testinin sonuçlarına bakılır (Şencan, 2005). Üçüncü test SPSS programında standart olarak sunulmaktadır ve faktör analizi menüsü içerisinde istendiği takdirde hesaplanabilmektedir. Her üç test için de kullanılan kriterler aşağıda ayrıntılı olarak verilmiştir.

\subsubsection{Katılımcı sayısı testi}

Birinci yol, Comrey ve Lee (1992) tarafından öngörülen Tablo 3'teki değerlere bakmaktır. Tabloya göre $n=583$ kişilik örneklem büyüklüğü çok iyi düzeydedir. 
Tablo 3

Katılımcı Sayısına göre Örneklem Büyüklüğünün Faktör Analizine Uygunluğu

Örneklem büyüklüğü

$\begin{array}{cc}50 & \text { Çok zayıf } \\ 100 & \text { Zayıf } \\ 150 & \text { Yeterli } \\ 200 & \text { Orta } \\ 300 & \text { İyi } \\ 500 & \text { Çok iyi } \\ 1000 & \text { Mükemmel. }\end{array}$

\subsubsection{Katılımcı sayısı - madde sayısı oranı testi}

i̇kinci yol, Bryman ve Cramer'in önerisi (2001) doğrultusunda, örneklem büyüklüğü için yeterli sayının en az değişken (madde) sayısının beş ya da onla çarpılmasıyla elde edilen sayı olarak alınmasıdır. Buna göre 9 madde için en az 45 - 90 kişilik bir örneklem yeterli olacaktır. Bu kritere göre de çok büyük bir örneklem $(n=583)$ kullanıldığı söylenebilir.

\subsubsection{Kaiser-Meyer-Olkin (KMO) testi}

Üçüncü yol, yeterli örneklem büyüklüğü için Kaiser-Meyer-Olkin KMO testinin sonucuna bakılmasıdır. KMO testi sonucunda Şencan'a (2005) göre aşağıdaki değerler üzerinden yorum yapılır: Bu kritere göre 9 ve 8 maddeli sürümlerin faktör analizine orta düzeyde ve 7 ve 6 maddeli sürümlerin faktör analizine zayıf düzeyde uygun olduğu söylenebilir. KMO değerine göre örneklemin faktör analizine uygunluğu Tablo 4'te gösterilmektedir.

Tablo 4

KMO Değerlerine göre Örneklem Büyüklügünün Faktör Analizine Uygunluğu

KMO değeri

\begin{tabular}{cc} 
KMO değeri & Faktör analizine uygunluğu \\
\hline$<0.50$ & Uygun değil \\
\hline $0.50-0.60$ & Kötü \\
\hline $0.60-0.70$ & Zayıf \\
\hline $0.70-0.80$ & Orta \\
\hline $0.80-0.90$ & İyi \\
\hline$>0.90$ & Mükemmel \\
\hline
\end{tabular}

\subsubsection{Bartlett Küresellik Testi}

Veri setinin faktör analizine uygunluğunu belirlemek için daha sonra Bartlett küresellik testi sonuçlarına bakılmıştır. Bu test çok değişkenli normalliği ölçer. Bu testte anlamlılık değerine bakılır ve anlamlılık değeri 0.05 ten küçük ise veri setinden faktör çıkarılabileceği, anlamlılık değeri 0.05 ten büyük ise veri seti için faktör analizi yapılamayacağı yorumu yapılır (Şencan, 2005). Ölçeğin tamamı ve en zayıf maddelerin (A, C ve G) sırasıyla çıkarılmasıyla geriye kalan 8,7 ve 6 maddelik ölçeklerin tamamı için anlamlılık (p) değeri 0.05 'ten küçük çıktığı için çoklu normalliğin sağlandığı ve Bartlett küresellik testi sonuçlarına göre eldeki veri setine faktör analizi uygulanabileceği yorumu yapılmıştır.

\subsubsection{Madde-Madde Korelasyon Matrislerinin İncelenmesi}

Veri setiyle faktör analizine başlamadan önce yapılması gereken bir başka şey korelasyon matrislerine (madde-madde ve anti-image) bakmaktır. Bu şekilde faktör analizine daha başlamadan analize uygun olmayan maddeler belirlenmiş olacaktır. Bu maddeler faktör analizine başlamadan önce çıkartılabilir. Madde madde korelasyonları $0.3^{\prime}$ ten küçük veya 
istatistiksel açıdan önemsiz ( $p>0.05$ ) maddelerde sorun olduğu düşünülür (Günüç ve Kayri, 2010) ve faktör analizine bu maddeler ile devam edilmez.

Tablo 5

Madde-Madde Korelasyon Matrisleri

\begin{tabular}{|c|c|c|c|c|c|c|c|c|c|}
\hline A & C & D & E & G & H & B & $\mathbf{F}$ & 1 & TOPLAM \\
\hline A & .202 & .173 & .206 & .106 & .245 & & & & 0.549 \\
\hline C & & .323 & .254 & .185 & .222 & & & & 0.545 \\
\hline D & & & .413 & .300 & .325 & & & & 0.653 \\
\hline$E$ & & & & .305 & .397 & & & & 0.696 \\
\hline G & & & & & .398 & & & & 0.596 \\
\hline H & & & & & & & & & 0.708 \\
\hline B & & & & & & & .478 & .423 & 0.812 \\
\hline $\mathbf{F}$ & & & & & & & & .392 & 0.761 \\
\hline I & & & & & & & & & 0.788 \\
\hline
\end{tabular}

Tablo 5'teki değerlere bakıldığında madde madde korelasyonları bakımından "iç güdülenme" faktörü için A,C ve G maddelerinde sorun olduğu görülmektedir. Diğer yandan "dış güdülenme" faktörü için bir problem olmadığı için faktör analizine maddelerin tamamı ile devam edilebilir. Sorunlu maddelerin analizin ilerleyen aşamalarında da sorunlar çıkaracağı öngörülebilir.

\subsubsection{Anti-Image Korelasyon Matrislerinin İncelenmesi}

Anti-Image Korelasyon Matrislerinde köşegende yer alan değerlerin düşük olması (< 0,50 ) durumunda bu maddeler ile faktör analizine devam edilmez (Altunışık, Coşkun, Bayraktaroğlu ve Yıldırım, 2005). Köşegen değerleri koyu karakterli olarak Tablo 6'da gösterilmektedir.

Tablo 6

Anti-Image Korelasyon Matrisleri

\begin{tabular}{cccccccccc} 
& $\mathbf{A}$ & $\mathbf{C}$ & $\mathbf{D}$ & $\mathbf{E}$ & $\mathbf{G}$ & $\mathbf{H}$ & $\mathbf{B}$ & $\mathbf{F}$ & $\mathbf{I}$ \\
\hline $\mathbf{A}$ &. $\mathbf{6 6 0}$ & -.239 & .660 & -.239 & .660 & -.239 & & & \\
C & -.239 & .701 & -.239 & .701 & -.239 & .701 & & & \\
$\mathbf{D}$ & .660 & -.239 & .660 & -.239 & .660 & -.239 & & & \\
E & -.239 & .701 & -.239 & .701 & -.239 & .701 & & & \\
$\mathbf{G}$ & .660 & -.239 & .660 & -.239 & .660 & -.239 & & & \\
H & -.239 & .701 & -.239 & .701 & -.239 & .701 & & & \\
B & & & & & & & .644 & -.374 & -.291 \\
F & & & & & & & -.374 & .660 & -.239 \\
I & & & & & & & -.291 & -.239 & .701 \\
\hline
\end{tabular}

Tablo 6'daki değerlere bakıldığında Anti-Image korelasyon matrislerinde 1. köşegende yer alan değerler sınırın çok üstünde olduğu için bu bakımdan bir problem olmadığı ve faktör analizine tüm maddelerle devam edilebileceği düşünülmüştür. Özetle, bu incelemeler sonucunda ölçeğin uygulanmasından elde edilen veri setinin açımlayıcı faktör analizine uygun olduğu sonucuna varılmıştır. 


\subsection{Açımlayıcı Faktör Analizinin Yapılması ve Yorumlanması}

Veri setinin faktör analizine uygunluğu bir önceki aşamada ortaya konulmuştu. Bu aşamada açımlayıcı faktör analizleri açıklanmıştır.

\subsubsection{Faktörleşme tekniğini belirleme}

Faktörleşme tekniği olarak temel bileşenler analizi, Temel eksen faktörleşme, Maksimum olasılık, Ağırlıklandırılmamış En Küçük Kareler, Genel En Küçük Kareler, Alfa Faktörleşme ve İmaj Faktörleşme tekniklerinin tamamı denenmiştir. Ancak tüm denemelerde en net faktör yapısı temel bileşenler analizi ile ortaya konulabildiği için faktörleşme tekniği sonuçları sadece bu teknik için bildirilmiştir. Bununla birlikte faktör analizinde farklı faktörleşme tekniklerinin genelde benzer sonuçlar verdiği de bilinmektedir.

\subsubsection{Döndürme tekniğini belirleme}

Döndürme tekniği olarak farklı döndürme tekniklerinden yararlanılmıştır. Bu teknikler Varimax, Direct Oblimin, Quartimax, Equamax ve Promax'tır. Döndürme tekniklerinden en temiz faktör yapısı eldeki veri seti için Kaiser normalizasyonu ile Varimax tekniği kullanarak bulunduğu için bu tekniği çalışmada kullanmanın yararlı olacağı düşünülmüştür. Temiz faktör yapıları 3 tekrarda (iterasyonda) ortaya çıkmıştır.

\subsubsection{Tutulacak faktör sayısını belirleme testleri}

Faktör analizinde kaç tane faktörün tutulacağı sorusunun yanıtı çeşitli şekillerde aranmıştır. Açımlayıcı faktör analizinde bu amaçla öncelikle Kaiser, Cartell, Velicer ve Horn olmak üzere dört farklı test yapılmaktadır. Bununla birlikte açıklanan toplam varyans miktarına, faktör yük değerlerine veya ortak faktör yük değerlerine bakılmaktadır.

\subsubsection{Dört test}

Kaiser, Cartell, Velicer ve Horn testlerinden sadece ilk ikisi SPSS programında standart olarak sunulmaktadır. Bu iki yöntem zayıf bulunmakta ve son iki yöntemin daha etkili ve özellikle son yöntemin faktör sayısını belirlemede en etkili olduğu bildirilmektedir (Ledesma \& Valero-Mora, 2007). Son iki yöntemi SPSS'te kullanmak için ilave komut satırları (Syntax) kullanmak gerekmektedir.
i.) K1- Kaiser'in birden büyük özdeğer (eigenvalue) kuralı
ii.) Cartell'in scree plot (yamaç birikinti grafiği) yöntemi
iii.) Velicer'in MAP(Minimum Average Partial) testi ve
iv.) Horn'un paralel analizi.

Bu dört yöntemin tutulacak faktör sayısını belirlemede kullanılabildiği ayrıntılı bir şekilde açıklanmıştır (Ledesma ve Valero-Mora, 2007). Bu çalışmada her ölçek için dört yöntem birden kullanılmış ve karşılaştırılmıştır. Böylelikle ilk iki yöntemin zayıflıklarını aşmak amaçlanmıştır. Dört yöntemin her birinden elde edilen değerler Tablo 7 ve Tablo 8'de sunulmaktadır.

\subsubsection{Açıklanan toplam varyans miktarına bakma}

Faktör analizinde kaç tane faktörün tutulacağı sorusunun yanıtı için bu sefer her faktör tarafından açıklanan toplam varyans miktarına bakılmıştır. Bu noktada farklı yaklaşımlar mevcuttur: Bir yaklaşıma göre toplam varyans miktarının 2/3 'ünü (\% 66) ilk olarak açıklayan faktör sayısı, bir başka yaklaşıma göre de toplam varyansın \% 50'sini açıklayan faktör sayısı önemlidir (Şekercioğlu, 2009). Bir başka kritere göre de sosyal bilimlerde toplam varyansın \% 
40’ı bile açıklansa yeterli kabul edilebilir (Büyüköztürk, 2007). Özellikle bu son kritere göre ölçek iki faktörlü yapıda kabul edildiği takdirde yeterli miktarda varyans açıklamaktadır.

\subsubsection{Faktör yük değerlerine bakma}

Faktör analizinde bir başka ölçüt olarak her bir faktör altında maddelerin yük değerlerinin en az 0.40 olması ve aynı maddenin diğer faktörler altındaki yük değerinin 0.30 altında olması gerektiği bildirilmiştir (Beavers ve ark., 2013). Analizlerde tüm maddeler için (en zayıf maddeler dahil) faktör yük değerleri 0.40 üzerinde çıkmıştır.

\subsection{Açımlayıcı Faktör Analizinin Yorumlanması}

Açımlayıcı Faktör Analizinde önce kullanılan veri setinin faktör analizine uygunluğunu ortaya koymak için KMO ve Bartlett küresellik testleri ve sonra tutulacak faktör sayısını belirlemek için Kaiser, Cartell, Velicer ve Horn testleri yapılmıştır. Ayrıca faktörler tarafından açıklanan toplam varyans miktarı, faktör yük değerleri, ortak varyans miktarları açıklanmıştır. Yapılan tüm testlerin sonuçları Tablo 7'de gösterilmektedir.

Tablo 7

Açımlayıcı Faktör Analizi Sonuçları

\begin{tabular}{|c|c|c|c|c|c|}
\hline \multicolumn{6}{|c|}{ Ölçek (9 madde) } \\
\hline \multicolumn{6}{|c|}{ Bartlett's küresellik testi and Kaiser-Meyer Olkin (KMO) testi sonuçları } \\
\hline \multicolumn{2}{|c|}{ KMO } & \multicolumn{2}{|c|}{.740} & & \\
\hline \multicolumn{2}{|c|}{ BARTLETT } & \multicolumn{2}{|c|}{.000} & & \\
\hline \multicolumn{6}{|c|}{ Tutulacak faktör sayısı } \\
\hline \multicolumn{2}{|c|}{ Kaiser's } & \multicolumn{2}{|c|}{2} & & \\
\hline \multicolumn{2}{|c|}{ Cartell's } & \multicolumn{2}{|c|}{2} & & \\
\hline \multicolumn{2}{|c|}{ Velicer's } & \multicolumn{2}{|c|}{2} & & \\
\hline \multicolumn{2}{|c|}{ Horn's } & \multicolumn{2}{|c|}{2} & & \\
\hline \multicolumn{6}{|c|}{ Faktörler tarafından açıklanan toplam varyans \% } \\
\hline \multicolumn{2}{|c|}{ 1. Faktör } & \multicolumn{2}{|c|}{27} & & \\
\hline \multicolumn{2}{|c|}{ 2. Faktör } & \multicolumn{2}{|c|}{49} & & \\
\hline & & \multicolumn{2}{|c|}{ Faktör Yükleri } & \multicolumn{2}{|c|}{ Orta Faktör Varyansları } \\
\hline \multicolumn{2}{|c|}{ MADDE } & Faktör 1 & Faktör 2 & Faktör 1 & Faktör 2 \\
\hline${ }_{*}^{* *} A$ & Oldum olası iyi bir öğrenciydim. & .404 & & .294 & \\
\hline${ }^{*} \mathrm{C}$ & Matematiği seviyorum. & .556 & & .309 & \\
\hline D & $\begin{array}{l}\text { Öğretme yeteneğine sahip olduğuma } \\
\text { inanıyorum. }\end{array}$ & .710 & & .511 & \\
\hline E & Çocuklarla çalışmaktan hoşlanıyorum. & .721 & & .520 & \\
\hline${ }^{*} \mathbf{G}$ & $\begin{array}{l}\text { Gelecek nesil üzerinde bir etki bırakmak } \\
\text { istiyorum. }\end{array}$ & .626 & & .393 & \\
\hline $\mathbf{H}$ & $\begin{array}{l}\text { Öğretmenliği ilgi çekici bir meslek olarak } \\
\text { görüyorum. }\end{array}$ & .691 & & .528 & \\
\hline B & $\begin{array}{l}\text { Öğretmenlikte iş bulma kolaylığı bana cazip } \\
\text { geliyor. }\end{array}$ & & .796 & & .642 \\
\hline $\mathbf{F}$ & Öğretmen maaşları bana cazip geliyor. & & .780 & & .609 \\
\hline $\mathbf{I}$ & $\begin{array}{l}\text { Öğretmen olmanın getirdiği uzun vadeli iş } \\
\text { güvenliğini istiyorum. }\end{array}$ & & .752 & & .567 \\
\hline${ }^{*} \mathrm{AFA}$ & $\begin{array}{l}\text { çlarına göre zayıf madde } \\
\text { uçlarına göre çok zayıf madde }\end{array}$ & & & & \\
\hline
\end{tabular}

Ölçek üzerinde yapılan AFA bulgularına göre $A, C$ ve $G$ maddelerinin yük değerleri yeterli olmakla birlikte diğerlerinden daha zayıf bulunmuştur. DFA güvenirlik analizlerinin sonuçlarına da bakarak bu maddelerin atılmasına karar verilebilir (Büyüköztürk, 2010). Birinci aşama AFA'da zayıf bulunan A, C ve $G$ maddelerinin sırayla her seferinde bir tek madde atılmasıyla yapılan tüm AFA testlerinin sonuçları Tablo 8'de gösterilmektedir. 
Tablo 8

Açımlayıcı Faktör Analizi Sonuçları

8 madde

7 madde

6 madde

(A maddesi çıkartılınca) (A ve C maddesi çıkartılınca) (A ve C maddesi çıkartılınca) Bartlett's küresellik testi and Kaiser-Meyer Olkin (KMO) testi sonuçları

\begin{tabular}{|c|c|c|c|c|c|c|c|c|c|}
\hline KMO & \multicolumn{3}{|c|}{0.716} & \multicolumn{3}{|c|}{0.691} & \multicolumn{3}{|c|}{0.654} \\
\hline BARTLETT & \multicolumn{3}{|c|}{0.000} & \multicolumn{3}{|c|}{0.000} & \multicolumn{3}{|c|}{0.000} \\
\hline \multicolumn{10}{|c|}{ Tutulacak faktör sayısı } \\
\hline Kaiser's & \multicolumn{3}{|c|}{2} & \multicolumn{3}{|c|}{2} & \multicolumn{3}{|c|}{2} \\
\hline Cartell's & \multicolumn{3}{|c|}{2} & \multicolumn{3}{|c|}{2} & \multicolumn{3}{|c|}{2} \\
\hline Velicer's & \multicolumn{3}{|c|}{2} & \multicolumn{3}{|c|}{2} & \multicolumn{3}{|c|}{2} \\
\hline Horn's & \multicolumn{3}{|c|}{2} & \multicolumn{3}{|c|}{2} & \multicolumn{3}{|c|}{2} \\
\hline \multicolumn{10}{|c|}{ Faktörler tarafından açıklanan toplam varyans \% } \\
\hline 1. Faktör & \multicolumn{3}{|c|}{28} & \multicolumn{3}{|c|}{30} & \multicolumn{3}{|c|}{33} \\
\hline 2. Faktör & \multicolumn{3}{|c|}{52} & \multicolumn{3}{|c|}{57} & \multicolumn{3}{|c|}{61} \\
\hline \multicolumn{10}{|c|}{ Faktör (F) Yükleri Orta Faktör Varyansları (OFV) } \\
\hline MADDE & F1 & $\mathbf{F 2}$ & OFV & F1 & F2 & OFV & F1 & F2 & OFV \\
\hline \multicolumn{10}{|l|}{$\mathbf{A}^{* *}$} \\
\hline $\mathrm{C}^{*}$ & .548 & & .302 & & & & & & \\
\hline D & .714 & & .517 & .708 & & .510 & .754 & & .580 \\
\hline $\mathrm{E}$ & .728 & & .531 & .743 & & .553 & .803 & & .646 \\
\hline $\mathbf{G}^{*}$ & .640 & & .409 & .673 & & .454 & & & \\
\hline H & .705 & & .550 & .736 & & .591 & .733 & & .585 \\
\hline B & & .800 & .648 & & .805 & & & .806 & .659 \\
\hline $\mathbf{F}$ & & .786 & .619 & & .788 & & & .786 & .621 \\
\hline $\mathrm{I}$ & & .767 & .592 & & .767 & & & & .592 \\
\hline
\end{tabular}

Bu testler ölçeğin iki faktörlü yapıda kullanılabileceğini göstermektedir. AFA sonuçlarına göre sadece $A, C$ ve $G$ maddeleri diğerlerinden daha zayıf bulunduğu için bu maddelerin atılması veya gözden geçirilmesi düşünülmelidir.

\subsection{Doğrulayıcı Faktör Analizinin Yapılması ve Yorumlanması}

DFA bilinen bir faktör yapısını, toplanan yeni bir veri setiyle doğrulamaya çalışır (Santor vd., 2011). Genellikle faktör yapısı bilinen ölçeklerin uyarlama sonucu yeni bir örneklemde doğrulanması için kullanılması nedeniyle bu yönteme doğrulayıcı faktör analizi ismi verilmektedir (Aydın, 2014). DFA ile maddelerin faktörler ve faktörlerin birbirleriyle ilişkilerini ortaya koymak mümkündür. Bu çalışmada yapılan DFA'da bir çok model uyum indeksi beraber değerlendirilmiştir. Çalışmada incelenen uyum indeksleri $\chi 2$ Kay Kare $(\chi 2)$ Uyum testi (ChiSquare Goodness of Fit), $\chi 2 / s d$, Yaklaşık Hataların Ortalama Kareköküdür (Root Mean Square Error of Approximation, RMSEA). Analizlerde ilk olarak $\chi 2$ Kay Kare ( $\chi 2)$ Uyum testi (Chi-Square Goodness of Fit), $\chi 2 / s d$, Yaklaşık Hataların Ortalama Karekökü (Root Mean Square Error of Approximation, RMSEA) değerlerine bakılmış ve alınan sonuçlara göre ölçek tek faktörlü modele iyi uyum göstermiştir (Büyüköztürk, 2007; Şekercioğlu, 2009; Santor vd., 2011). DFA analizleri en zayıf maddelerin çıkarılmasıyla tekrar edilmiştir. Tekrar yapılan analizlerde ölçeğin iki faktörlü modele uyumu devam etmiştir. Ölçekten madde çıkarılması kuramsal olarak desteklenmesi gereken ve mantıksal olarak anlaşılabilir nedenlerden kaynaklanan bir durumdur. Genel olarak uyarlaması yapılan bir ölçekten madde çıkarmama yoluna gidilmesi kuramsal yapıyı korumak ve orijinal ölçekle yapılan çalışmalardan elde edilen sonuçlarla karşılaştırma yapabilmek amacıyla tercih edilmektedir (Aydın, 2014). Bu çalışmada bu iki olasılıktan biri tercih edilmemiş, DFA'da elde edilen sonuçlar maddelerin atılmasıyla ortaya çıkan farklı durumlar için verilerek karar verme işlemi okuyucuya bırakılmıştır. Bu çalışmada kullanılan doğrulayıcı faktör analizinin sonuçları Şekil 1'de gösterilmiştir. 


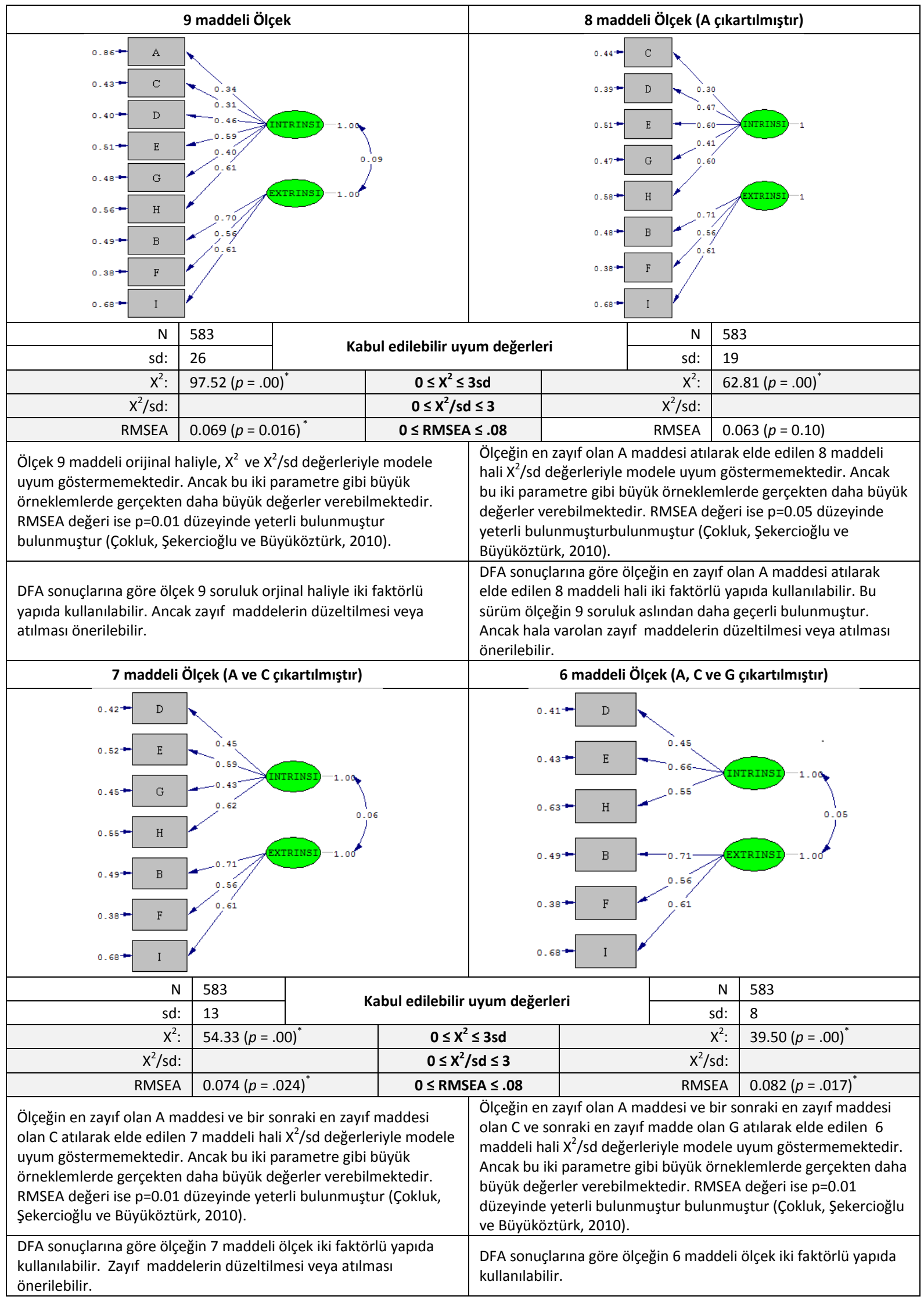

\section{Şekil 1. Doğrulayıcı Faktör Analizi Sonuçları}


Şekil 1'de gösterilen DFA sonuçlarına göre ölçek iki faktörlü yapıda kullanılabilir. Bununla birlikte ölçekten en zayıf olan A maddesi atıldığı zaman DFA'nın daha iyi sonuçlar verdiği görülmektedir. Tüm bu sonuçlara göre ölçek 9 maddeli ve iki faktörlü yapıda kullanılabilir ancak zayıf olan maddelerin, özellikle sırayla A, C ve G'nin gözden geçirilmesi veya atılması önerilebilir.

\subsection{Güvenirlik Analizinin Yapılması ve Yorumlanması}

Bu bölümde ölçeğin iki faktörünün güvenirlik değerleri açıklanacaktır.

\subsubsection{Madde - Toplam korelasyonlarının incelenmesi}

Madde - toplam korelasyonlarına bakarak güvenirliği düşük olan maddeler ve ölçeğin tamamı için güvenirlik kestirimi yapılabilir. Bu amaçla hesaplanan madde-toplam korelasyonları Tablo 9'da gösterilmektedir. Madde-toplam korelasyonu (nokta çift serili korelasyon) klasik test kuramında maddenin ayırt edicilik parametresi olarak ifade edilir ve 0,30 üzerindeki değerler için maddenin ayırt etme kalitesinin yeterli olduğu yorumu yapılır (Derebaşı, 2004). Maddeler, her iki faktör için ayrı gruplarda gösterilmiştir.

Tablo 9

Madde - Toplam Korelasyonu

\begin{tabular}{|c|c|c|c|c|c|c|c|c|c|}
\hline & \multicolumn{6}{|c|}{ İç } & \multicolumn{3}{|c|}{ Dış } \\
\hline & A & C & D & E & G & $\mathbf{H}$ & B & $\mathbf{F}$ & I \\
\hline 9 madde & .549 & .545 & .653 & .696 & .596 & .708 & .811 & .767 & .789 \\
\hline 8 madde & $x$ & .556 & .690 & .726 & .646 & .727 & .811 & .767 & .789 \\
\hline 7 madde & $x$ & $x$ & .687 & .748 & .678 & .758 & .811 & .767 & .789 \\
\hline 6 madde & $x$ & $x$ & .723 & .796 & $x$ & .773 & .811 & .767 & .789 \\
\hline
\end{tabular}

Tablo 9'da gösterilen madde-toplam korelasyonlarına göre 9 maddeli tam ölçekten, en zayıf maddelerin sırayla atılmasıyla elde edilen 6 maddeli ölçeğe kadar tüm durumlarda ölçekte güvenilir soruların yer aldığı yorumu yapılabilir. Bu açıdan 9 maddeden 6 maddeye kadar ölçekteki maddeler için "iç güdülenme" faktöründe güvenirlik artarken "dış güdülenme" faktöründe madde eksiltme yapılmadığı için güvenirlik değişmemiştir.

Sonuç olarak madde-toplam korelasyonu bakımından en güvenilir görünen ölçek 6 maddeli ölçektir. Dokuz maddeli tam ölçekte $A, C$ ve $G$ maddeleri diğer maddelerden daha zayıf görünmektedir. Bu yüzden 9 maddeli tam ölçeğin kullanımında bu durumun dikkate alınması önerilir.

\subsubsection{Nokta ve güven aralıkları için Cronbach alfa ve Mc Donald omega katsayılarının hesaplanması}

Güvenirlik hesaplamaları için madde-toplam korelasyonlarından sonra veri seti üzerinde nokta ve güven aralıkları için Cronbach alfa ve Mc Donald omega hesaplamaları yapılmıştır. Omega katsayısının tek boyutluluk ve normallik ihlallerinden daha az etkilendiği ve alfa'ya göre daha güvenilir sonuçlar verdiği ve GLB katsayısının güvenirlik için bir alt sınır değeri verdiği ve bu yüzden değerli olduğu ifade edilmiştir (Peters, 2014). Son olarak, hem omega hem de alfa için tek bir değer hesaplamak yerine güven aralığı bulmanın daha uygun olacağını savunan araştırmacılar vardır (Dunn vd., 2013; Peters, 2014). Yukarıdaki gerekçelerle güven aralıkları da hesaplanmıştır.

Tablo 10 
Cronbach alfa ve Mc Donald omega Güvenirlik Değerleri

\begin{tabular}{|c|c|c|c|c|c|c|c|c|c|c|c|c|c|}
\hline & \multicolumn{7}{|c|}{ Oran ölçeği kestirimleri } & \multicolumn{6}{|c|}{ Sıralama ölçeği kestirimleri } \\
\hline & \multicolumn{5}{|c|}{ Nokta kestirimleri } & \multicolumn{2}{|c|}{ Güven aralıkları } & \multicolumn{4}{|c|}{ Nokta kestirimleri } & \multicolumn{2}{|c|}{ Güven aralıkları } \\
\hline & 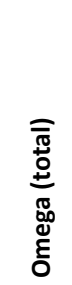 & 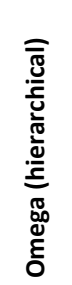 & 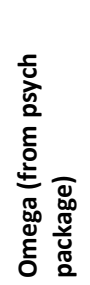 & 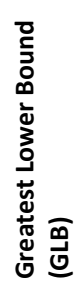 & 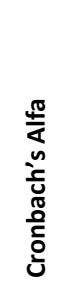 & 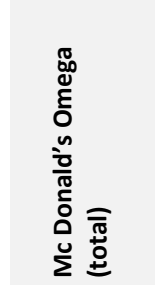 & 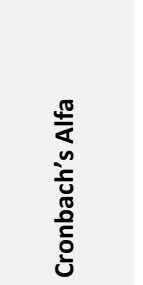 & 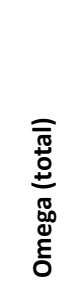 & 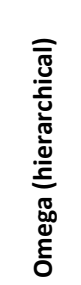 & 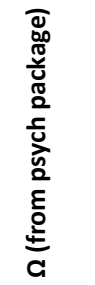 & 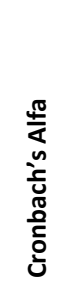 & 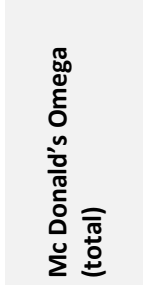 & 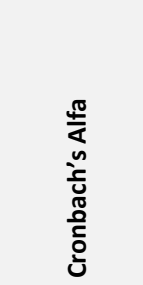 \\
\hline & $\Omega$ & $\Omega$ & $\Omega$ & GLB & $\alpha$ & $\Omega$ & $\alpha$ & $\Omega$ & $\Omega$ & $\Omega$ & $\alpha$ & $\Omega$ & $\alpha$ \\
\hline \multicolumn{14}{|c|}{9 madde } \\
\hline iç̧ & 0.69 & 0.57 & 0.78 & 0.75 & 0.69 & {$[0.66,0.73]$} & {$[0.65,0.72]$} & 0.80 & 0.62 & 0.80 & 0.74 & {$[0.71,0.78]$} & {$[0.71,0.77]$} \\
\hline Dış & 0.69 & 0.70 & 0.78 & 0.70 & 0.69 & {$[0.65,0.74]$} & {$[0.65,0.73]$} & 0.85 & 0.75 & 0.85 & 0.75 & {$[0.72,0.79]$} & {$[0.72,0.79]$} \\
\hline \multicolumn{14}{|c|}{8 madde } \\
\hline iç & 0.70 & 0.59 & 0.74 & 0.74 & 0.69 & {$[0.66,0.74]$} & {$[0.65,0.73]$} & 0.80 & 0.63 & 0.80 & 0.74 & {$[0.72,0.78]$} & {$[0.71,0.78]$} \\
\hline Dış & 0.69 & 0.70 & 0.78 & 0.70 & 0.69 & {$[0.65,0.74]$} & {$[0.65,0.73]$} & 0.85 & 0.75 & 0.85 & 0.75 & {$[0.72,0.79]$} & {$[0.72,0.79]$} \\
\hline \multicolumn{14}{|c|}{7 madde } \\
\hline ìç & 0.69 & 0.62 & 0.73 & 0.73 & 0.68 & {$[0.65,0.73]$} & {$[0.64,0.73]$} & 0.79 & 0.69 & 0.79 & 0.74 & {$[0.71,0.78]$} & {$[0.71,0.78]$} \\
\hline Dış & 0.69 & 0.70 & 0.78 & 0.70 & 0.69 & {$[0.65,0.74]$} & {$[0.65,0.73]$} & 0.85 & 0.75 & 0.85 & 0.75 & {$[0.72,0.79]$} & {$[0.72,0.79]$} \\
\hline \multicolumn{14}{|c|}{6 madde } \\
\hline iç̧ & 0.65 & 0.65 & 0.73 & 0.67 & 0.64 & {$[0.60,0.70]$} & {$[0.59,0.69]$} & 0.80 & 0.71 & 0.80 & 0.71 & {$[0.67,0.75]$} & {$[0.67,0.75]$} \\
\hline Dış & 0.69 & 0.70 & 0.78 & 0.70 & 0.69 & {$[0.65,0.74]$} & {$[0.65,0.73]$} & 0.85 & 0.75 & 0.85 & 0.75 & {$[0.72,0.79]$} & {$[0.72,0.79]$} \\
\hline
\end{tabular}

Tablo 10'da güvenirlik hesaplamaları gösterilmiştir. Ölçeğin tamamı için Cronbach alfa güvenirliği 0.75 ve $\mathrm{Mc}$ Donald omega güvenirliği 0.85 olarak bulunmuştur. Yapılan hesaplamalara göre hem nokta ve güven aralığı kestirimlerinin tamamında, ayrıca omega, alfa ve GLB değerlerinin tamamında yeterli sonuçlar bulunmuştur (Dunn vd., 2013; Peters, 2014). Maddelere verilen cevaplar dört seçenekli olduğu için bu ölçek için güvenirlik hesaplamalarında oran ölçeği yerine sıralama ölçeği kestirimlerine bakmak daha doğru sonuçlar verebilir. Sıralama ölçeği kestirimleri her iki faktör için çok iyi düzeyde bulunmuştur. Bu sonuçlarla ölçeğin her iki faktörü için de güvenilir olduğu görülmektedir. En zayıf olan $A, C$ ve $G$ maddelerini atmak gerektiği durumlarda da güvenirliğin korunduğu söylenebilir.

Tablo 11

Analizler Sonucunda En Güçlüden En Zayıfa Doğru Ölçek Maddeleri

\begin{tabular}{|c|c|c|c|c|c|c|}
\hline & & & & Güdülenme & & leler \\
\hline \multirow{5}{*}{ 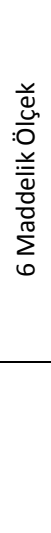 } & \multirow{3}{*}{ 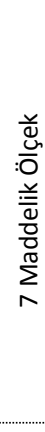 } & \multirow{5}{*}{ 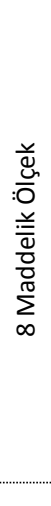 } & \multirow{5}{*}{ 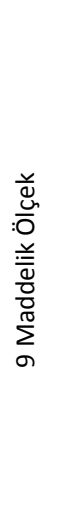 } & $\stackrel{m}{a}$ & $\begin{array}{l}\text { B } \\
F\end{array}$ & $\begin{array}{l}\text { Öğretmenlikte iş bulma kolaylı̆̆ı bana cazip geliyor. } \\
\text { Öğretmen maaşları bana cazip geliyor. } \\
\text { Öğretmen olmanın getirdiği uzun vadeli iş güvenliğini istiyorum. }\end{array}$ \\
\hline & & & & \multirow{4}{*}{ un } & $\begin{array}{l}\mathrm{E} \\
\mathrm{D}\end{array}$ & $\begin{array}{l}\text { Öğretmenliği ilgi çekici bir meslek olarak görüyorum. } \\
\text { Çocuklarla çalışmaktan hoşlanıyorum. } \\
\text { Öğretme yeteneğine sahip olduğuma inanıyorum. }\end{array}$ \\
\hline & & & & & G & Gelecek nesil üzerinde bir etki bırakmak istiyorum. \\
\hline & & & & & C & Matematiği seviyorum. \\
\hline & & & & & & Oldum olası iyi bir öğrenciydim. \\
\hline
\end{tabular}


Ölçeğin maddelerinin analizler sonucu elde edilen sıralaması Tablo 11'de gösterilmektedir. Analiz sonuçlarının nasıl yorumlandığı bundan sonraki bölümde açıklanmıştır.

\section{TARTIŞMA VE SONUÇ}

Bu çalışma matematik ve farklı branşlarda öğretmen adayları için önemli bir araştırma konusu olarak görülen öğretmenlik mesleği için güdülenme nedenlerini (Behymer ve Cockriel, 1998; Çermik, Doğan ve Şahin, 2010; Friedman, 2016; Kniveton, 2004; Şeker, Deniz ve Görgen, 2015) ortaya koyan 8 soruluk TEDS-M “Öğretmenlik Mesleği için Güdülenme” ölçeğinin Türkçe'ye uyarlanması ve geçerlik ve güvenirliğinin kanıtlanması sürecini açıklamıştır. Çalışmada yapı geçerliliği ve istatistiksel geçerlik kanıtları olarak örtük değişken analizlerinden açımlayıcı ve doğrulayıcı faktör analizleri (Büyüköztürk, 2007; Şekercioğlu, 2009) ve güvenirlik kanıtları olarak madde-toplam korelasyonları (Şekercioğlu, 2009) ve alfa-omega hesaplamaları (Dunn vd., 2013; Peters, 2014) kullanılmıştır.

TEDS-M “Öğretmenlik Mesleği için Güdülenme” ölçeğinin İngilizce aslının dışsal ve içsel nedenler şeklinde iki faktörlü olduğu bildirilmiştir (Tatto, 2008). Bu çalışmada kullanılan AFA ve DFA testleri ölçeğin Türkçe uyarlamasının da dışsal ve içsel nedenler şeklinde iki faktörlü olduğunu doğrulamıştır. Mayr (1998) tarafından geliştirilen ve Atav ve Altınoğlu (2013) tarafından Türkçe'ye uyarlanmış olan Meslek ve Alan Seçiminde Motivasyon Ölçeği'nin meslek seçimiyle ilgili olan 12 maddelik bölümü de içsel ve dışsal nedenler olarak iki faktörlü yapıda bulunmuştur (Ekinci, 2016). Bu bulgu literatürde öğretmen ve öğretmen adaylarının öğretmenliği tercih etme nedenlerini genelde içsel ve dışsal olarak sınıflandıran yazınla uyumludur (Bastick, 2000; Behymer ve Cockriel, 1998; Boz ve Boz, 2008; Çermik, Doğan ve Şahin, 2010; Friedman, 2016; Kaya ve Yıldırım, 2015; Kniveton, 2004; Papanastasiou ve Papanastasiou, 1997; 1998; Saban, 2003; Şeker, Deniz ve Görgen, 2015). Bu çalışmadan sonra öğretmen adaylarının öğretmen olma nedenlerinin ele alınabileceği kategoriler arasında içsel ve dışsal nedenlerin de mutlaka bulunması gerektiği sonucuna ulaşılmıştır.

Diğer yandan faktör analizlerinde yaygın uygulama tek bir ideal ölçeğe ulaşmaktır (Beavers vd., 2013; Henson ve Roberts, 2006; Tabachnick \& Fidell, 2001). Bu çalışmada tüm analizlerin bulguları ayrıntılı olarak sunularak geçerli ve güvenilir bulunan ölçeğe ait istatistikler verilmiştir. Ölçekte yer alan maddelerle ilgili aşağıdaki sonuçlara ulaşılmıştır: Dokuz maddelik tam ölçeği ilköğretim matematik öğretmeni adayları için kullanmak mümkündür. Ancak ölçeğin bir maddesinin çok zayıf ve iki maddesinin zayıf olduğunu dikkate almak gerekmektedir. Ölçekteki zayıf maddeler çıkarılarak farklı ihtiyaçlara göre kullanılabilir. Örneğin C maddesi çıkarıldığında ölçeği matematikten bağımsız bir “Öğretmenlik Mesleği için Güdülenme” ölçeği olarak kullanmak mümkün olabilir. C maddesi çıkarıldığı zaman geriye kalan maddeler matematikle doğrudan ilişkili değildir. Ancak buna benzer şekilde madde atma işinin ilgili alanyazın, bağlam ve kuramlarla desteklenmesi gerekecektir. Ölçeğin "Bu bir neden değil", "Bu küçük bir neden", "Bu önemli bir neden" ve "Bu en önemli nedenlerden biri" şeklinde 4 seçenekli yerine "Kısmen katılmıyorum"dan, "Kesinlikle katılıyorum"a kadar 5 seçenekli bir biçimde uygulanması önerilebilir. "Oldum olası iyi bir öğrenciydim" şeklindeki A maddesi en zayıf maddedir. Bunun nedeni iyi bir öğrenci olmak ile öğretmenliği tercih etme arasındaki ilişkinin anlaşılmaması olabilir. Bunun yerine madde örneğin "Çok başarılı olduğum okul hayatında çalışmak için" şeklinde değiştirilebilir. "Matematiği seviyorum" şeklindeki C maddesi A maddesinden sonraki en zayıf maddedir. Bu madde de öğretmenliği tercih etme ile şöyle ilişkilendirilebilir: "Matematikle ilgili bir işte çalışmayı seviyorum". Ayrıca, "Gelecek nesil üzerinde bir etki bırakmak istiyorum" şeklindeki G maddesi de zayıftır. Bunun nedeni dil olabilir. Bu madde şöyle değiştirilebilir: "Bir öğretmen olarak gelecek nesilleri etkilemek istiyorum". En çok dikkat çeken madde C maddesi olmuştur. Bu madde tek başına ölçeği matematikle ilişkili veya ilişkisiz hale getirmektedir. Bu madde çıkarıldığı veya uyarlandığı 
zaman ölçeğin farklı alanlardan öğretmen adayları için de kullanılabileceği öngörülebilir. Bu nedenle araştırmacıların ölçeği "matematikli" ve "matematiksiz" olmak üzere farklı amaçlar için kullanması mümkün olabilir. Ölçek AFA, DFA ve güvenirlik analizlerinin tamamında yeterli - çok iyi arasında parametreler göstermektedir. Ayrıca yeterli çeşitlilik ve ayrıntıyı da sunma gücünde görünmektedir.

Bu çalışmada uyarlaması yapılan ve geçerlik ve güvenirliği test edilen ölçek bundan sonra büyük ölçekli uluslararası karşılaştırmalı yeni çalışmalarda kullanılabilir. Araştırmacılar bu ölçeği kullanarak öğretmen adaylarının öğretmenlik mesleği için güdülenme nedenlerini ortaya koyabilir ve çeşitli değişkenler açısından inceleyebilir. İçsel ve dışsal güdülenme nedenlerinden hangilerinin öğretmenlik mesleği tercihinde daha etkili olduğu farklı alandan ve farklı yetenek gruplarından öğretmenler üzerinde araştırılabilir. Yapılan bazı araştırmalar içsel nedenlerin matematik öğretmenliğini seçmede dışsal nedenlerden daha önemli olduğunu göstermiştir (Ekinci, 2016; Yılmaz ve Doğan, 2015). Diğer yandan, başka bazı araştırmalar dışsal nedenlerin öğretmenlik mesleğini seçmede içsel nedenlerden daha önemli olduğunu göstermiştir (Bastick, 2000; Boz ve Boz, 2008; Papanastasiou ve Papanastasiou, 1997; 1998; Saban, 2003). Araştırmacıların benzer çalışmaları diğer alan öğretmenlikleri için de yapmaları yazına önemli katkı sağlayacaktır.

\section{KAYNAKÇA}

Altunışık, R., Coşkun, R., Bayraktaroğlu, S., \& Yıldırım, E. (2010). Sosyal Bilimlerde Araştırma Yöntemleri: SPSS Uygulamalı. Sakarya yayıncilık.

Atav, E. ve Altunoğlu, B. D. (2013). Meslek ve alan seçiminde motivasyon ölçeğinin Türkçe formunun geçerlik ve güvenirlik çalışması. Hacettepe Üniversitesi Eğitim Fakültesi Dergisi, 28(2), 58-70.

Aydın, S. (2014). Ilköğretim matematik öğretmeni adaylarının öğretme bilgilerinin, inanışlarının ve öğrenme fırsatlarının üniversiteler ve TEDS-M sonuçlarına göre karşılaştırılması. Yayınlanmamış doktora tezi. Karadeniz Teknik Üniversitesi, Eğitim Bilimleri Enstitüsü, Trabzon.

Bartholomew, D. J., Knott, M., \& Moustaki, I. (2011). Latent variable models and factor analysis: A unified approach (Vol. 904). John Wiley \& Sons.

Bastick, T. (2000). Why teacher trainees choose the teaching profession? Comparing trainees in metropolitan and developing countries. International Review of Education, 46(3/4), 343-349.

Baumert, J., \& Kunter, M. (2006). Stichwort: Professionelle Kompetenz von Lehrkräften. Zeitschrift für Erziehungswissenschaft, 9(4), 469-520.

Beavers, A. S., Lounsbury, J. W., Richards, J. K., Huck, S. W., Skolits, G. J., \& Esquivel, S. L. (2013). Practical considerations for using exploratory factor analysis in educational research. Practical assessment, research \& evaluation, 18(6), 1-13.

Behymer, J., \& Cockriel, I. W. (1988). Career choice conflict. Journal of Career Development, 15(2), 134140.

Beswick, K., Ashman, D., Callingham, R., \& McBain, D. (2011). Teachers' and pre-service teachers' confidence to teach primary school mathematics. In Australian Association for Research in Education Conference (AARE 2011 Conference) Proceedings (pp. 1-10).

Bryman, A., \& Cramer, D. (2001). Quantitative data analysis with SPSS release 10 for Windows. New York.

Boz, Y. ve Boz, N. (2008). Kimya ve matematik öğretmen adaylarının öğretmen olma nedenleri. Kastamonu Eğitim Dergisi, 16(1), 137-144.

Büyüköztürk, Ş. (2007). Sosyal Bilimler için Veri Analizi El Kitabı: Istatistik, Araştırma Deseni, SPSS Uygulamaları ve Yorum. (Yedinci Baskı). Ankara: PEGEM A Yayıncılık. 
Comrey, A. L. and Lee, H. B. (2013). A first course in factor analysis. Psychology Press.

Çermik, H., Doğan, B. ve Şahin, A., (2010). Sınıf Öğretmenliği Öğretmen Adaylarının Öğretmenlik Mesleğini Tercih Sebepleri. Pamukkale Üniversitesi Eğitim Fakültesi Dergisi, 28 (2), ss. 201-212.

Derebaşı, I. (2004). Evlilik doyumu ölçeğinin (MSI-R) madde cevap kuramına dayalı olarak psikometrik özelliklerinin incelenmesi ve adaptasyon çalışması. Yayınlanmamış Doktora Tezi, Ege Üniversitesi Sosyal Bilimler Enstitüsü, İzmir.

Dunn, T. J., Baguley, T., \& Brunsden, V. (2014). From alfa to omega: A practical solution to the pervasive problem of internal consistency estimation. British Journal of Psychology, 105(3), 399-412.

Efklides, A., Kuhl, J., \& Sorrentino, R. M. (2001). Trends and prospects in motivation research. Dordrecht; Boston; London: Kluwer Academic.

Ekinci, N. (2017). Öğretmen Adaylarının Öğretmenlik Mesleği ve Alan Seçiminde Etkili Olan Motivasyonel Etkenler. Illköğretim Online, 16(1).

Friedman, I. A. (2016). Being a teacher: altruistic and narcissistic expectations of pre-service teachers. Teachers and Teaching, 22(5), 625-648.

Günüç, S. ve Kayri, M. (2010). Türkiye'de internet bağımlılık profili ve internet bağımlılık ölçeğinin geliştirilmesi: Geçerlik-güvenirlik çalışması. Hacettepe Üniversitesi Eğitim Fakültesi Dergisi, 39(39).

Henson, R. K., \& Roberts, J. K. (2006). Use of exploratory factor analysis in published research common errors and some comment on improved practice. Educational and Psychological measurement, 66(3), 393-416.

Howell, D. C. (2007). Statistical methods for psychology (6th ed.). Belmont, CA: Thomson Wadsworth.

Kaya, E. ve Yıldırım, T. (2015). Fen Fakültesi Biyoloji Bölümü Öğrencilerinin Gözüyle Öğretmenlik. Bayburt Eğitim Fakültesi Dergisi, 10(2).

Kniveton, B. H. (2004). The influences and motivations on which students base their choice of career. Research in Education, 72, 47-57.

Kunter, M., \& Pohlmann, B. (2009). Lehrer. In E. Wild ve J. Möller (Hrsg.), Pädagogische Psychologie (pp. 261-280). Berlin: Springer-Verlag.

Ledesma, R. D., \& Valero-Mora, P. (2007). Determining the number of factors to retain in EFA: An easyto-use computer program for carrying out parallel analysis. Practical assessment, research \& evaluation, 12(2), 1-11.

Lloyd, J., Bond, F. W. \& Flaxman, P. (2017). Work-Related Self-Efficacy as a Moderator of the Impact of a Worksite Stress Management Training Intervention: Intrinsic Work Motivation as a Higher Order Condition of Effect. Journal of Occupational Health Psychology, 22(1), pp. 115-127.

Mayr, J. (1998). Motive für die studien- und berufswahl. fragebögen zur erkundung des lehrens und lernens an der pädagogischen akademie. Eine Materialsammlung. Pädagogische Akademie der Diözese Linz.

Papanastasiou, C., \& Papanastasiou, E. (1997). Factors that influence students to become teachers. Educational Research and Evaluation, 3(4), 305-316.

Papanastasiou, C., \& Papanastasiou, E. (1998). What influences students to choose the elementary education major: The case of Cyprus. Mediterranean Journal of Educational Studies, 3, 35-45.

Peters, G. J. Y. (2014). The alfa and the omega of scale reliability and validity: why and how to abandon Cronbach's alfa and the route towards more comprehensive assessment of scale quality. European Health Psychologist, 16(2), 56-69.

R Development Core Team. (2014) . R: A language and environment for Statistical Computing. Vienna, Austria. 1 Nisan 2016 tarihinde http://www.r-project.org/ adresinden alınmıştır. 
Richardson, P. W., \& Watt, H. M. G. (2006). Who chooses teaching and why? Profiling characteristics and motivations across three Australian Universities, Asia-Pacific Journal of Teacher Education, 34(1), 27-56.

Rosnow, R. L., \& Rosenthal, R. (2008). Assessing the effect size of outcome research, in Nezu, Arthur M. and Nezu, Christine Maguth (Eds), Evidence-based outcome research: A practical guide to conducting randomized controlled trials for psychosocial interventions, (pp. 379-401). New York, NY, US: Oxford University Press, xxv, 486 pp.

Santor, D. A., Haggerty, J. L., Lévesque, J. F., Burge, F., Beaulieu, M. D., Gass, D., \& Pineault, R. (2011). An overview of confirmatory factor analysis and item response analysis applied to instruments to evaluate primary healthcare. Healthcare Policy, 7 (Spec Issue), 79.

Şaban, A. (2003). A Turkish profile of prospective elementary school teachers and their views of teaching. Teaching and Teacher Education, 19, 829-846.

Şekercioğlu, G. (2009). Çocuklar için benlik algısı profilinin uyarlanması ve faktör yapısının farklı değişkenlere göre eşitliğinin test edilmesi. Yayınlanmamış Doktora Tezi, Ankara Üniversitesi, Ankara.

Seker, H., Deniz, S., \& Gorgen, I. (2015). Pre-service teachers motivations toward teaching profession and their opinions about the pedagogic formation program. Educational Research and Reviews, 10(10), 1403-1414.

Şencan, H. (2005). Sosyal ve Davranışsal Ölçümlerde Güvenirlik ve Geçerlik. (Birinci Baskı). Ankara: Seçkin Yayınları.

Tabachnick B. G. and Fidel, L. S. (2001). Using multivariate statistics (fourth edition). MA: Allyn \& Bacon, Inc.

Tabachnick, B. G., \& Fidell, L. S. (2007). Using multivariate statistics (5th ed.). Boston: Allyn and Bacon.

Tatto, M. T., Ingvarson, L., Schwille, J., Peck, R., Senk, S. L. and Rowley, G. (2008). Teacher education and development study in mathematics (TEDS-M): Policy, Practice, and readiness to teach primary and secondary mathematics. Conceptual framework. International Association for the Evaluation of Educational Achievement. Herengracht 487, Amsterdam, 1017 BT, The Netherlands.

Yılmaz, N. ve Doğan, N. (2015). İlköğretim matematik öğretmen adaylarının meslek tercihlerini etkileyen faktörler: Hacettepe Üniversitesi Örneği. Abant İzzet Baysal Üniversitesi Eğitim Fakültesi Dergisi, 15(1), 405-421. 
Ek 1: TEDS - M Öğretmenlik Mesleği için Güdülenme Ölçeği Türkçe Formu

Aşağıdakilerden her birinin, sizin öğretmen olma nedenlerinizi ne ölçüde tanımladığını işaretleyiniz.

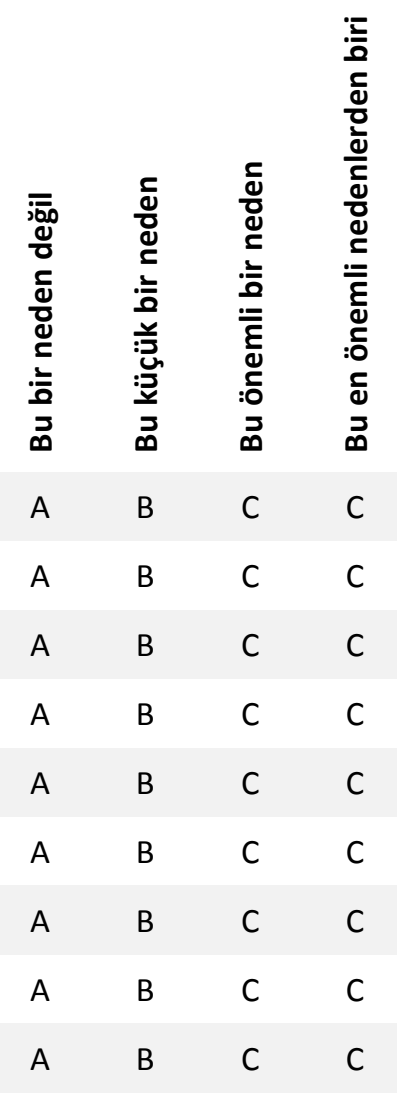

1. Oldum olası iyi bir öğrenciydim.

2. Öğretmenlikte iş bulma kolaylığı bana cazip geliyor.

3. Matematiği seviyorum.

4. Öğretme yeteneğine sahip olduğuma inanıyorum.

5. Çocuklarla çalışmaktan hoşlanıyorum.

6. Öğretmen maaşları bana cazip geliyor.

7. Gelecek nesil üzerinde bir etki bırakmak istiyorum.

8. Öğretmenliği ilgi çekici bir meslek olarak görüyorum.

9. Öğretmen olmanın getirdiği uzun vadeli iş güvenliğini istiyorum. 


\begin{abstract}
SUMMARY
Preservice/inservice teachers' reasons/intentions/motivations to become teachers have been investigated by several researchers (Behymer and Cockriel, 1998; Çermik, Doğan and Şahin, 2010; Friedman, 2016; Kniveton, 2004; Şeker, Deniz and Görgen, 2015). Çermik et al. (2010), explained this interest with the important role of teaching profession in a country's social, economical and cultural development. Other researchers revealed that some professional motivation(intention) factors (ie. intrinsic factors) are more correlated to attract better recruits than other factors (i.e. extrinsic factors) (Bastick, 2000; Boz ve Boz, 2008; Papanastasiou and Papanastasiou, 1997; 1998; Saban, 2003). Friedman (2016), investigated the reasons of 160 preservice teachers to become s teacher and showed that they had 4 different type of reasons which are 1. True extrinsic, 2. Parental extrinsic, 3. True intrinsic and 4. Pragmatic intrinsic. Kaya and Yıldırım (2015), showed in their study that 160 biology majors had basically two groups of reasons to become teachers which are intrinsic and extrinsic. Çermik et al. (2010), attempted to determine 157 preservice primary teachers' reasons to become teachers. They found 4 basic types of reasons as 1 . Extrinsic, 2. Intrinsic, 3. Pragmatic and 4. Ego-centered. Other researchers showed that extrinsic reasons dominate intrinsic reasons whereas intrinsic reasons had more positive results (Bastick, 2000; Boz and Boz, 2008; Papanastasiou and Papanastasiou, 1997; 1998; Saban, 2003). All the previous work mentioned above show that identifying (preservice) teachers' reasons to become teachers are important for several reasons. Such studies are still needed both in the World and in Turkey. However, it is also evident that powerful tools to measure reasons to become a teacher in Turkey are lacking. TEDS-M scale for "Intentions/Motivation to become a teacher" is an important tool that can fill this gap.
\end{abstract}

In order to identify Turkish preservice elementary teachers' reasons to become a teacher and to compare these reasons with other countries, TEDS-M (2008) "Intentions/Motivation to become a teacher" scale was adapted from English into Turkish in the context of a national project supported by TÜBITAK. Then validity and reliability evidence were gathered for the Turkish adaptation. This paper reports the results of this validity and reliability tests.

The research problems in this study were stated as:

1. What is the degree of validity for the adapted TEDS-M (2008) "Intentions/Motivation to become a teacher" scale?

2. What is the degree of reliability for the adapted TEDS-M (2008) "Intentions/Motivation to become a teacher" scale?

For these aims, TEDS-M (2008) "Intentions/Motivation to be a teacher" scale was adapted from English into Turkish. The original scale has 9 items, 3 of which are related to extrinsic reasons and the remaining 6 are related to intrinsic reasons. Multiple translation and multiple editing(revision) strategy were used for adaptation. The adapted scale was applied to 583 senior preservice elementary mathematics teachers studying in 7 universities randomly selected from 7 different geographical regions of Turkey. The sample represented the population in terms of location, gender or initial achievement levels. Then a satisfactory dataset was obtained which then underwent validity and reliability analyses. Exploratory and confirmatory factor analyses were conducted as proofs of validity. These tests are variations of latent variable analyses which are based on different assumptions. Likewise, reliability analyses were conducted and reported in detail. For example, in contrast to common practice, Cronbach's alfa and Mc Donald's omega were calculated both for ordinal and interval scales and for point estimates and confidence intervals. Several authors find omega as a more precise measure of reliability. In addition, finding confidence intervals both for omega and alfa provides more detailed reliability expressions. Moreover, the alfa calculation in SPSS software assumes that the responses to items were metrical. In reality, the responses to items are categorical or at best ordinal. In this study, the reliability estimations were made also for ordinal scale assumption. The findings were evaluated by an expert group and the researchers. The exploratory factor analyses were made using SPSS 22 . The confirmatory factor analyses were made using Lisrel 9.0. The reliability analyses were made using $R$ software. 
The preliminary tests showed that the dataset obtained from the application of the adapted scale to a nationally representative sample was suitable for factor analyses. When we look at the total variance explained, the results of several tests such as Kaiser's eigenvalue bigger than one, factor loads and communalities and the clear factor structure, the exploratory factor analyses revealed that 2 factors (latent traits) should be retained. The confirmatory factor analyses showed that scale can be accepted to have two factors when one looks at the results of goodness-of-fit tests such as $\operatorname{RMSEA}<0,08$ and other parameters such GFI, CFI or NFI. The analyses showed an overall fit of the scale to two different latent traits as "extrinsic" and "intrinsic" reasons. Some items were found relatively weak in all these validity analyses.

The reliability analyses showed good to excellent results for both factors. Mc Donald's omega and Cronbach's alfa calculations provided comparable results which makes us think that the dataset did not violate normality assumptions much. The reliability parameters for ordinal scale assumption showed higher values which is consistent with the fact that the responses to items are at best ordinal.

After the validity and reliability analyses for all legitimate versions, the findings were presented for all versions and the decisions were left to the reader. Finally, four legitimate versions of the scale with different validity and reliability parameters all of which exceeding the acceptable limits were delivered to the literature and researchers. From these versions 9 items original scale and 6 items version were found somewhat weaker than the 8 and 7 items versions. The 8 items version might be used for a measurement pertaining mathematics (preservice) teachers and the 7 items version might be used as a mathematics-proof version. The findings of the validity and reliability analyses showed that the adapted scale and its versions exceed the acceptable limits quoted from the relevant literature. 